\title{
Assessing Speech Production Based on Interference Picture Naming and Games for Children
}

\author{
Siti Eka Soniawati \\ University of Indonesia \\ Depok 16624, Indonesia \\ ekasonia41@ymail.com
}

\begin{abstract}
Abtsract-This study aims to determine the ability of vocabulary production of children in Bekasi. The method used is using image naming interference and picture guess games. Picture-naming is one method of latency between images and semantic meaning with unrelated spangles (Starreveld, 2016). This is done to determine the effect of the effects, namely how the percentage of stimulus that has the potential to compete in affecting access and production of vocabulary in the method of naming the image. While the game guess images are used to determine the ability of children about the concept of meaning based on the given stimulus. The data were collected by two experiments, namely, first, the method of image naming interference. Testing was performed with five preschoolers as respondents, with an age range of 4-6 years. The second experiment, the method of guessing game images to test the understanding of children with the help of stimulus provided by researchers. Both experiments each use six images with noun category. The results showed that vocabulary production is influenced by several factors. First, the word frequency, the more often the word is used the faster we can call it when it needs it. Second, the lack of it. A word that can be easily described or imagined will be easier to understand and remember. Third, semantic relation. Certain words bring a closer connection of meaning to another particular word and not to another particular word.
\end{abstract}

Keywords-speech production; memory; picturenaming interference; games or guess the picture

\section{INTRODUCTION}

The development of children's language interesting to study. They were able to learn any language in the vicinity (Savile, 1973). The process of speaking, good talk, listen, read, or write, can not be separated from the mental processes on which to base when we hear / read, understand, and remember can be explained by a cognitive system in humans (Mar'at, 2005, p. 34). Meanwhile, according to Goodluck (1996) the development of child language acquisition begins from perkembnagan comprehension; phonology; sintaksi; morphology and vocabulary. In the view of Dardjowidjojo (2016, p. 260) describes how children define the meaning of a word is not easy. From the feedback that is, the child must analyze all manner so that its meaning was eventually acquired the same meaning used by adults. There are strategies that followed (Golinkoff et al 1994 Gleason and Ratner, 1998, p. 361), children's wear, such as the reference strategy assumes that the word must refer to objects, actions, processes, attributes. With this strategy the new child to hear suau new word will paste the word meaning in one of the references above.

The statement relates to the model of vocabulary in the brain (mental lexicon), or referred to the vocabulary in the brain. The words in the mental lexicon makes the tissues. Once activated, a sign of unified lexical stimuli other lexical signs. And this is due to a larger network active (Aitchison, 1994). Therefore, the semantic information into the production-related stimulus vocabulary (Schriefers, 1990). One approach to speech production stages is filed by Willem Levelt, which was later adapted into a mathematical model called WEAVER ++ (Taxler 2012, p. 39). According to this model, it is important that we have outlined in pengujaran sentence is that when we draw up the ideas we expressed in our speech, not automatically directly to the production of speech embodied in sound. There are a series of steps that we've been through from initial conception of the idea to the process of articulation of the sentence in order to convey our ideas. WEAVER ++ portray these stages systematically. This stage occurs sequentially and simultaneously where each phase will produce a product that will enable a subsequent stage.

Other than disclosed above, in this study, semantic interference occurs as a swindler (distractor) associated semantics that are part of the response, in addition to receiving the activation of perceptual input, activated by the concept of interest through the activation of which spread to the concept distaktor (Collina et al, 2013). While Mahon et al. (2007) assumes that the semantic effect depending on the criteria of the target and distaktor response (response exclusion hypothesis).

Naming the image is used to determine the production process one's vocabulary. In the selection of words (lexical selection) semantic substitution indicates that the concept of a word that in our memory associated with a number of other words concepts that have meaning to the word proximity. When we think of a concept we will mengaktifkansatu concept word stored in our long-term memory, other concepts are related and have a close meaning to the concept would be indirectly activated. 
In this study focused on answering some problems, such as how the theory of features and concepts of knowledge to help someone in the process of language production.

The focus of this study are (1) how the conceptualization of a factor in the production of a good vocabulary in the storage and retrieval word? (2) how the production vocabulary of a person based on the theory of features and knowledge?

This study aimed (1) to determine the production capability of the vocabulary children aged 6-7 years with the method of naming pictures and picture guessing game, it becomes a researcher assumption that the conceptualization becomes important role in storing and recalling vocabulary. (2) determine the child's understanding of the concept of the meaning of vocabulary with the help of stimulus guessing game images based on the theory of features and knowledge.

\section{LITERATURE REVIEW}

This study uses several theories, namely:

\section{A. Production Languages}

Bock \& Levelt (1994) via Dardjowidjojo (2016, pp. 117119) states that the process in producing a narrative divided into four levels, namely (1) the level of message (message), (2) the functional level, (3) the level of positional and (4) the level of phonology. The level of functional and positional included in the category gramatical encoding while the level of phonological included in phonological encoding. Meanwhile, addressing the language production, Zenzi M. Griffin and Victor S. Ferreira (2006) in Traxler and Morton AG states that:

Language production is logically divided into three major steps to: Deciding what to express it (conceptualization), Determining how to express it (formulation), and expressing it (articulation).

Logically, language production is divided into three main steps, that is, deciding what is delivered (conceptualization), determines how penyamapiannya (formulation), and menyamapaikannya (articulation).

At the level of the message, the speaker collect the notion-the notion of meaning to be conveyed to the hearer. At the functional level, forms a lexical and grammatical information corresponding to the message will be selected and determined its function. On the next level, positional processing, lexical forms that have been the structured order of discharge. That is, the speaker chose everywhere lexicon which should appear first and everywhere lexicon that must come later. Lexical sorting process is accompanied by affixation election. At the final level, the processing result of positional sent to the phonological level to be realized in the form of sound. The embodiment of the sound itself is a complex skill:

B. Memory, Storage, and Retrieval word utterances Production Process

Basically, it would be easy diretrif a word when the word is often used (Dardjowidjojo, 2016, p. 169). In the semantic field of words that have a certain characteristic included in the same field. For example, words such as mangoes, oranges, apples, rambutan and pineapple included in the same field, namely, fruit. The words are stored in warehouses word in the brain called the mental lexicon. Kempen (via Mar'at, 2011, p. 41) states that the mental lexicon contains all the knowledge of the speaker associated with words in the vocabulary repertoire or in other words contains the meaning of words, morphological characteristics, characteristics of syntactic, pronunciation, and spelling. In line with the views Kempen, Aitchiston (1990, p. 194) states that the mental lexicon has two main components,

\section{Features Theory of Knowledge}

The theory says that the concept features formed from a group of smaller units called features. The concept of object called a cat, for example, has a bunch of features, namely, among others, (a) quadrupeds, (b) double-edged, (c) Eared two, (d) nosed one, (e) a mustache, (f) hairy (g) is black, white, Soklat, striped (but not green and purple, etc.), (h) voiced miaow. Dardjowidjojo (2014, pp. 181-182) explains that the concept has the essential features that restrict it from other concepts.

While the theory of knowledge is an extension of the theory of features. Reeves et al in Gleaso and Ratner (1998, p. 191) explains that this theory is based on psychology and contextualism. Humans generally have knowledge of the essence of an object. Conceptualization, terntu context raises the link between the features of a concept with other concepts in a category. Between concepts and knowledge is unity. That is, the feature list is not enough to represent the whole concept. The list is only used as a starting point to then go deeper dig our knowledge.

\section{Component Meaning}

Components of meaning analyzing every word or lexical elements consist of one or several elements that together make up the meaning of words or meaning of the lexical items. This analysis assumes any lexical item has or does not have a feature that distinguishes it from other elements (Pateda, 2008, p. 273).

Eve Clark (1973 in Dardjowijojo, 2000, p. 247) explains that every word has a beam of semantic features. For the goat said, for example, has a semantic feature [+ object], [+ animal], [+ quadruped], [+ hairy], [+ horns], [+ caudate] and some other features. In the early acquisition of meaning, the child can only be picked up in part of all the semantic features. Suppose taken only feature [+ object], [+ animal], and [+ quadruped] the goats will tergelembungkan be oxen, and horses. Based on subsequent inputs children revise original concept until finally came the same meaning as the meaning adults. In this analysis it is assumed that the grains lexical in the lexicon of every language can be analyzed such that the primary meaning of a limited set of components that are universal.

Another opinion, according to Lehrer (1974, p. 46) defines the components of meaning or semantic feature is a theoretical construct that can provide the characteristics of a language vocabulary. each unit can be defined lexical meaning on the basis of components owned by the lexical unit. 


\section{METHOD}

This study uses a qualitative method Definition of experimental research. The criteria for the respondents involved in the study described as follows.

1) Two children (male/female) with an age range of 6-7 years;

2) Having normal vision;

3) Indonesian native speakers;

4) Having the ability to read (can spell and combine at least two syllables).

Techniques of data retrieval is done by direct observation, by direct observation of the respondents. While the data collection tool used twice experimentation. First, test the language production based on the method of naming the image. Secondly, test language production based on the method to figure out the image.

Materials research, four objects image selected for the first and second experiments. In the first experiment, the image (noun category) were chosen with the neighborhood children the names of animals and fruits. Each picture was posing (distaktor) related to the target (semantically). The distractor appear in large letters and bright colors to prevent participants ignore the detractors. As for the second experiment, mentioned characteristic features of which refers to one of the images based on analysis of components of meaning or semantic features.

\section{1) The first experiment}

In this experiment, was used to test the child's understanding of the presented image to call it as quickly and accurately as possible. As a comparison, given the image by posing (distractors) which have similarities, namely semantics. It was used as a trigger stimulus to produce a vocabulary of children according to the child's memory.

\section{2) A second experiment}

This paper starts from the understanding of language production by applying some of the characteristic features of a noun based on the analysis of components of meaning. The term semantic features or characteristics of the semantics of a word is the distinguishing feature of the device that are intrinsic meaning or represents, semantic features of a word that collectively captured as a concept or meaning of the word (Subroto, 1986, p. 33). These experiments used to see the ability of children with associated response theory of meaning in producing vocabulary.

\section{RESUlT AND DisCUSSION}

Tests given to respondents twice. Details of the observations as follows.

\section{A. The First Experiment}

Respondents were given a naming test image (picturenaming). Respondents were asked to mention appropriately tested for the image name. It is used to determine the competence of lexical and concepts in the production of children's language.

The observation is based on the results of the first experimental test has been conducted on five respondents as follows:

1) Children already have a concept stored in the memory of the object being tested.

2) There is a tendency difference in tempo / time when the child mentioned objects. It was triggered by semantic distractors. Nearly the whole, the image of the tested responded by children properly. However, interestingly children actually negates the answer.

Consider the results of the study after receiving treatment with the data given as follows.

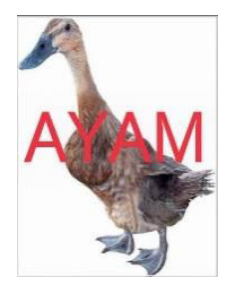

Picture. 1

a) Researcher : Never seen this picture? respondents 2: It's a duck, not a chicken.

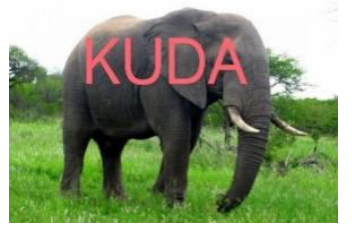

Picture. 2

b) Researcher : Akbar, never seen this picture ga? respondent 1 : Kok horse, high .. Elephant kan kan fat.

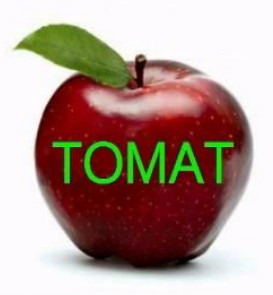

Picture. 3

c) researcher :Let's see, never seen this picture?

respondent 1 :Tomatoes but like apples yes aunt ..

researcher : So this is a picture of what? 
respondent $1 \quad$ : Red Apple. Red tomatoes. Apple

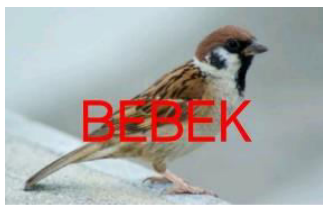

Figure 4.

d) researcher : Hayoo never seen this picture? respondents 2 Birds .. duck right that had been researcher : Oh difference huh?

respondents 2 : Yeah I saw in Izam dong there are ducks

The response given above can then be analyzed that children aged 6-7 years own a concept stored in memory. All knowledgeassociated with words in the vocabulary repertoire or in other words contains the meaning of words, morphological traits, traits syntax, pronunciation, and spelling.

The first experimental results indicated that:

a) There is a tendency of children aged 6-7 years in the process of speaking aided by the influence of environmental factors. Kids convey the intended meaning it takes a series of cognition in meretrif a vocabulary. More details see the results of the experiment number two. When researchers gave the test naming images of image Elephant Riding distractor, the response of respondents associated the test is as follows. Kok horse, high .. Elephant kan kan fat. Evidence that the semantic features have been produced in the child cognition. If the analogy, semantic features between horses and elephants as follows.

TABLE I. COMPONENTS ANALYSIS MEANING HORSE AND ELEPHANT

\begin{tabular}{|l|c|c|}
\hline \multirow{2}{*}{ Component meaning } & \multicolumn{2}{|c|}{ Leksem } \\
\cline { 2 - 3 } & Horse & Elephant \\
\hline beast & + & + \\
\hline Four legs & + & + \\
\hline mammal & + & + \\
\hline Big bodied & - & + \\
\hline eared width & - & + \\
\hline Trunked & - & + \\
\hline
\end{tabular}

Based on the above table, based on research, the concept of which is owned by the child in the memory is the concept of a fat-analogize elephant elephant large size while the horse was high.

b) Based on the study the number one and four, the first image shows a picture of a duck with chicken distractor. While the picture is a bird with a distractor four ducks. Interestingly, respondents to grasp the semantic features in their cognition. If analogous semantic features between birds and chickens as follows.
TABLE II. COMPONENTS ANALYSIS MEANING DUCK AND BIRD

\begin{tabular}{|l|c|c|}
\hline \multirow{2}{*}{ Component meaning } & \multicolumn{2}{|c|}{ Leksem } \\
\cline { 2 - 3 } & Duck & Bird \\
\hline fowl & + & + \\
\hline two-legged & + & + \\
\hline have wings & - & + \\
\hline can swim & + & - \\
\hline have wings & - & + \\
\hline Beep "wek-wek" & + & - \\
\hline
\end{tabular}

According to the table above and the results of the study, found that the theory of features and knowledge (Dardjowidjojo, 2014, pp. 181-182) gave the stimulus related to the production of language. feature theory says that the concept is formed from a group of small units. While the theory of knowledge aterdapat conceptualization, certain konterks which led to a link between the features from one concept to another within a category.

\section{B. A Second Experiment (Memory and Retrieval Word)}

Basically, it would be easy diretrif a word when the word is often used (Dardjowidjojo, 2016, p. 169). Note the results below.

A second experiment, using a guess image based on the analysis involves two components of meaning with the same respondents. Below are the test results of observation of the methods of guessing the picture.

TABLE III. SUMMARY OF RESULTS AGAINST TWO RESPONDENTS

\begin{tabular}{|l|c|c|}
\hline \multicolumn{1}{|c|}{ Features semantics } & \multicolumn{2}{|c|}{ Results Answers Respondents } \\
\cline { 2 - 3 } $\begin{array}{l}\text { Poultry, pets, coined } \\
\text { the foot membrane, life } \\
\text { on land, swimmer, egg- } \\
\text { laying, the sound of } \\
\text { "wek-wek" }\end{array}$ & Duck & Duck \\
\hline $\begin{array}{l}\text { Animals, namely those } \\
\text { that live in the zoo, big, } \\
\text { wide-eared, long } \\
\text { belalalai }\end{array}$ & Elephant & Elephant \\
\hline $\begin{array}{l}\text { Fruits, rounded shape, } \\
\text { usually red, when ripe } \\
\text { sweet taste }\end{array}$ & Confused & Apple \\
\hline $\begin{array}{l}\text { Birds, animals, two- } \\
\text { legged, } \\
\text { feathered, fly winged, }\end{array}$ & & Bird \\
\hline
\end{tabular}

\section{Semantic Structures}

Based on the above table, the five respondents take advantage of features relating to the object to which it refers. For example, in the data number (1) it appears the word chair. In the minds of the respondents can be seen: [bernyawa], [+ object], [-manusia], [+ noun] [+ seating legged and lean]. The semantic structure of the four images were tested seeks to reveal how a child understands the meaning as language production ability.

The results of this second experiment showed that the understanding of language production is influenced by knowledge, particularly the dimensions of lexical and 
language production. This reinforces the idea by Stowe and Hahn (2013), in a similar study in the production of language-no knowledge that is activated in one's memory. Interestingly, Baddeley (2003) made a synthesis of the research that someone has the concept in the form of a speech. There is a working memory-term temporary storage system and have an impact in the production of language.

Referring to previous research, the above results imply that there are skills possessed by a child related to the semantic object names. A child is able to master the vocabulary involving semantic features that exist in their concept and environmental factors are very influential in the production of language.

\section{Synthesis of The First and Second Experiment}

This study departs from the basic language production especially children. Of two experiments conducted, it is known that a word is produced only when there is a previous comprehension. That is, people can meretrif said only when it has been storing it in memory of her words earlier. Language production trends influenced by concepts that are stored in memory. As both if pursed, will lead to one goal, which is to interpret the concept as proof of language production. In the first experiment known the results that respondents were able to answer correctly. Then, the second experiment, forming pegertian that a child in producing a language known to absorb the existing features. It is not something that is easy to say. If the first experiment, semantic and phonological features to compete in the production process said. This is supported by the second experiment, that in order to understand the meaning of the word diperlukaan theory. It was like diungkpakan of theory based on those features and theory of knowledge (Dardjowodjojo, 2014).

Theory features basically states that the word has a set of features, or traits, entrusted become an integral part of the word (Dardjowidjojo, 2014, P. 89). In a second experiment the results table, for example, for record number 2. Said Elephants [+ animal], [-bernyawa], [+ big], [+ legged big], [+ trunk]. These features are overall concept dinamankan membentu elephants. Therefore, the above experiments provide answers that features of a word helps intuition in the production of language. strengthen peelitian result, knowledge-based theory, this theory is still based on the theory of features, but expanded. This means that people can understand speech or word if intuitively mengeal advance of the concept and the word is correct based on the knowledge.

\section{V.CONCLUSION}

From the research results by applying the two experiments showed that basically retrieval word is influenced by various factors. First, the frequency of the word: the more often a word is used the faster we can call on when you need it. Second, ketergambaran. A word that can be easily described or can imagine it would be easy to understand and remember. The words of concrete, for example, more and to understand and remember than abstract words. The third factor, semantic linkage. Certain words carry meaning closer linkage to another specific word and not to certain other words. (Dardjowijojo, 2014, pp. 8788).
Production of one's language, especially children starting from the concept of meaning. Memory or the memory of a child will help menetrif word based on the concept that coinciding based on form and experience. The process was not easy. It takes time and effort meretrif words exactly how berdasrakn various criteria. In the process meretrif said, adapaun diperlukaan semantic role. Features semantic support so that one is able to properly said. In a word meaning mehamai needed some theories that support based on those features and experience possessed by language and culture.

Based on the analysis, the respondents tend to correct in naming the image. However, there are differences when the respondents name the images with associated semantic distractors. From these observations, it is known-when children read words in pictures (distractor), for example, data (1) there are ducks with distractor by naming the chickens. From understanding the above, there are between phonological and semantic competence. The concept of chickens and ducks were compared suit the features of the concept. So in the end, will have objects that qualify.

Dependent child language acquisition than he knew and environmental impact in the percentage of vocabulary for a child. It is expected that further research can explore more about the production of children's language.

\section{References}

Aitchison, J. (1994). Words in the main. Blackwell. Garman, M. (1990). Psycholinguistics. CUP.

Baddeley, A, (2003). Working memory and language: an overview. International journal of language and communication disorders, 36(3), pp. 189-208.

Collina, et al. Word. (2012). Production and the pictureword interference paradigm: the role of Learning. J. Psycholinguist Res, 42, 461-473.

Dardjowidjojo, Soenjono. (2014). Psycholinguistics: introduction to human understanding. Jakarta: Yayasan Obor Indonesia Atma Jaya.

Golinkoff, Mervis and Kathryn Hirsh-Pasek. (1994). Early object labels: the case for a developmental lexical principles framework. Journal of Child Language, 21.

Goodluck, Helen. (1996). Language acquistion: a linguistic introduction. Massachusetts, USA: Blackwell Publishers Inc.

Lehrer, A. (1974). Semantic fields and lexical structure. Amsterdam: North Holland.

Lisa Gershkoff-Stowe and Erin R. Hahn. (2013). Word comprehension and production asymmetries in children and adults. Elsevier. Journal of Experimental Child Psychology, 114, 489-509.

Mahon, BZ, Costa, A., Peterson, R., Vargas, KA, \& Caramazza, A. (2007). Lexical selection is not by competition: a reinterpretation of semantic interference 
and facilitation effects in the picture-word interference paradigm. Journal of Experimental Psychology: Learning, Memory and Cognition, 33(3), 503-535.

Mar'at, S. (2005). Psycholinguistics: an introduction. Bandung: PT. Refika Aditama.

Pateda, Mansoer. (2008). Lexical semantics (second edition). Jakarta: Rineka Reserved.

Simone and Simona Collina. (2015). The picture-word interference paradigm: gramatical class effects in lexical production. J Psycholinguist Res.

Starreveld, Peter A and Wido La Heij. (2016). Picture-word interference is a stroop effect: a theoretical analysis and new empirical findings. Journal Psychon Bull. Rev. Doi10.3758/s13423-016-1167-6.

Schriefers, Herbert and Gabriella Vigliocco. (2001). Speech production. Journal of psycholinguistics Research, 22. Elsevier Ltd.

Traxler, Matthew J. (2012). Introduction to psycholinguistics: understanding language science. John Wiley \& Sons. US.

Wedhawati. Medan (2002). Lexical and componential analysis. Journal of Linguistics Indonesia, Yogyakarta.

Zenzi M. Griffin and Victor S. Ferreira. (2006). Properties of spoken language production. In Mathew J. Traxler and Morton A. Gernbacher, eds., Handbook of psycholinguistics (Second Edition). Amsterdam: Elsevier. 